\title{
Snake venomics of Bothrops punctatus, a semi-arboreal pitviper species from Antioquia, Colombia
}

Bothrops punctatus is an endangered, semi-arboreal pitviper species distributed in Panamá, Colombia, and Ecuador, whose venom is poorly characterized. In the present work, the protein composition of this venom was profiled using the 'snake venomics' analytical strategy. Decomplexation of the crude venom by RP-HPLC and SDS-PAGE, followed by tandem mass spectrometry of tryptic digests, showed that it consists of proteins assigned to at least nine snake toxin families. Metalloproteinases are predominant in this secretion ( $41.5 \%$ of the total proteins), followed by C-type lectin/lectin-like proteins (16.7\%), bradykinin-potentiating peptides (10.7\%), phospholipases A2 (9.3\%), serine proteinases (5.4\%), disintegrins (3.8\%), L-amino acid oxidases (3.1\%), vascular endothelial growth factors (1.7\%), and cysteine-rich secretory proteins (1.2\%). Altogether, $6.6 \%$ of the proteins were not identified. In vitro, the venom exhibited proteolytic, phospholipase A2, and L-amino acid oxidase activities, as well as angiotensin-converting enzyme (ACE)-inhibitory activity, in agreement with the obtained proteomic profile. Cytotoxic activity on murine $\mathrm{C} 2 \mathrm{C} 12$ myoblasts was negative, suggesting that the majority of venom phospholipases A2 likely belong to the acidic type, which often lack major toxic effects. The protein composition of $B$. punctatus venom shows a good correlation with toxic activities here and previously reported, and adds further data in support of the wide diversity of strategies that have evolved in snake venoms to subdue prey, as increasingly being revealed by proteomic analyses. (219 words) 
1 Snake venomics of Bothrops punctatus, a semi-arboreal pitviper species from

2

3

4

5

6

7

8

9

10

11

12

5

\section{Antioquia, Colombia}

(3)

6

7

8

${ }^{1}$ Programa de Ofidismo/Escorpionismo, ${ }^{2}$ Facultad de Química Farmacéutica, and

${ }^{3}$ Escuela de Microbiología, Universidad de Antioquia UdeA, Calle 70 No.52-21, Medellín,

1 Colombia; ${ }^{4}$ Instituto Clodomiro Picado, Facultad de Microbiología, Universidad de Costa Rica, San José 11501, Costa Rica

Running title: Snake venomics of Bothrops punctatus

13 Keywords: Snake venom, Viperidae, proteomics, Bothrops punctatus

* Corresponding author:

Bruno Lomonte, $\mathrm{PhD}$

Professor

Instituto Clodomiro Picado

Facultad de Microbiología

Universidad de Costa Rica

San José 11501, COSTA RICA

bruno.lomonte@ucr.ac.cr 


\section{ABSTRACT}

Bothrops punctatus is an endangered, semi-arboreal pitviper species distributed in

16 Panamá, Colombia, and Ecuador, whose venom is poorly characterized. In the present work, the

17 protein composition of this venom was profiled using the 'snake venomics' analytical strategy.

18 Decomplexation of the crude venom by RP-HPLC and SDS-PAGE, followed by tandem mass

19 spectrometry of tryptic digests, showed that it consists of proteins assigned to at least nine snake

20 toxin families. Metalloproteinases are predominant in this secretion ( $41.5 \%$ of the total proteins),

21 followed by C-type lectin/lectin-like proteins (16.7\%), bradykinin-potentiating peptides (10.7\%),

22 phospholipases $\mathrm{A}_{2}$ (9.3\%), serine proteinases (5.4\%), disintegrins (3.8\%), L-amino acid oxidases

$23(3.1 \%)$, vascular endothelial growth factors (1.7\%), and cysteine-rich secretory proteins $(1.2 \%)$.

24 Altogether, $6.6 \%$ of the proteins were not identified. In vitro, the venom exhibited proteolytic,

25 phospholipase $\mathrm{A}_{2}$, and L-amino acid oxidase activities, as well as angiotensin-converting enzyme

26 (ACE)-inhibitory activity, in agreement with the obtained proteomic profile. Cytotoxic activity on

27 murine $\mathrm{C} 2 \mathrm{C} 12$ myoblasts was negative, suggesting that the majority of venom phospholipases $\mathrm{A}_{2}$

28 likely belong to the acidic type, which often lack major toxic effects. The protein composition of

29 B. punctatus venom shows a good correlation with toxic activities here and previously reported,

30 and adds further data in support of the wide diversity of strategies that have evolved in snake

31 venoms to subdue prey, as increasingly being revealed by proteomic analyses.

32 (219 words) 


\section{INTRODUCTION}

34 The Chocoan forest lancehead, Bothrops punctatus, known in Colombia as 'rabo de

35 chucha', is a large semi-arboreal pitviper, ranging from 1.0 to $1.5 \mathrm{~m}$ in length. Campbell \& Lamar

36 (2004) described its distribution from the Pacific foothills and coastal plain of eastern Panamá

37 through western Colombia to northwestern Ecuador, with an altitudinal range between 1350 and

382300 m. In Colombia, Daza et al. (2005) reported the occurence of B. punctatus in the Cauca and

39 Magdalena river basins of Antioquia to eastern Chocó. Although Bothrops species are clearly

40 predominant in the epidemiology of snakebite accidents occuring in Colombia (Otero, 1994;

41 Paredes, 2012), published reports of proven envenomings caused by B. punctatus appear to be

42 rare. The protein composition of the venom of this species has not been investigated, although at

43 least two reports characterized its toxicological properties, in comparative studies of snake

44 venoms from Colombia (Otero et al., 1992) and Ecuador (Kuch et al., 1996), respectively. The

45 lethal potency of this venom to mice was highest among the different Bothrops venoms analyzed

46 in these two studies, being only second to that of Crotalus durissus terrificus venom (Otero et al.,

47 1992; Kuch et al., 1996). Due to the lack of knowledge on the venom composition of B. punctata,

48 this work aimed at characterizing its proteomic profile using the 'snake venomics' analytical

49 strategy (Calvete et al., 2007; Calvete 2011), in combination with the assessment of its enzymatic

50 or toxic activities in vitro.

\section{METHODS}

\section{Venom}

$54 \quad$ Venom was obtained from two adult Bothrops punctatus specimens collected in the

55 eastern region of the Department of Antioquia, and kept in captivity at the Serpentarium of

56 Universidad de Antioquia, Medellín, Colombia, under institutional permission for Programa de

57 Ofidismo/Escorpionismo. Venom samples were centrifuged to remove debris, pooled, lyophilized 
and stored at $-20^{\circ} \mathrm{C}$. In some functional assays, pooled venom obtained from more than 30

59 specimens of Bothrops asper, collected in the Departments of Antioquia and Chocó, was included

60 for comparative purposes.

61

62 Proteomic profiling

For reverse-phase (RP) HPLC separations, $2.5 \mathrm{mg}$ of venom was dissolved in $200 \mu \mathrm{L}$ of water containing $0.1 \%$ trifluoroacetic acid (TFA; solution A), centrifuged for 5 min at $15,000 \times g$, and loaded on $\mathrm{C}_{18}$ column $(250 \times 4.6 \mathrm{~mm}, 5 \mu \mathrm{m}$ particle; Teknokroma $)$ using an Agilent 1200 chromatograph with monitoring at $215 \mathrm{~nm}$. Elution was performed at $1 \mathrm{~mL} / \mathrm{min}$ by applying a gradient towards solution B (acetonitrile, containing $0.1 \%$ TFA), as follows: $0 \%$ B for 5 min, 0 15\% B over $10 \mathrm{~min}, 15-45 \%$ B over $60 \mathrm{~min}, 45-70 \%$ B over $10 \mathrm{~min}$, and 70\% B over 9 min (Lomonte et al., 2014). Fractions were collected manually, dried in a vacuum centrifuge, and further separated by SDS-PAGE under reducing or non-reducing conditions, using $12 \%$ gels. Protein bands were excised from Coomassie blue R-250-stained gels and subjected to reduction with dithiothreitol $(10 \mathrm{mM})$ and alkylation with iodoacetamide $(50 \mathrm{mM})$, followed by in-gel digestion with sequencing grade bovine trypsin (in $25 \mathrm{mM}$ ammonium bicarbonate, $10 \%$ acetonitrile) overnight on an automated processor (ProGest Digilab), according to the manufacturer. The resulting peptide mixtures were analyzed by MALDI-TOF-TOF mass spectrometry on an Applied Biosystems 4800-Plus instrument. Peptides were mixed with an equal volume of saturated $\alpha$-CHCA matrix (in 50\% acetonitrile, $0.1 \% \mathrm{TFA}$ ), spotted $(1 \mu \mathrm{L}$ ) onto Opti-TOF 384-well plates, dried, and analyzed in positive reflector mode. Spectra were acquired using a laser intensity of 3000 and 1500 shots/spectrum, using as external standards CalMix-5

80 (ABSciex) spotted on the same plate. Up to 10 precursor peaks from each MS spectrum were

81 selected for automated collision-induced dissociation MS/MS spectra acquisition at $2 \mathrm{kV}$, in 82 positive mode (500 shots/spectrum, laser intensity of 3000). The resulting spectra were analyzed 
83 using ProteinPilot v.4 (ABSciex) against the UniProt/SwissProt database using the Paragon ${ }^{\circledR}$

84 algorithm at a confidence level of $\geq 95 \%$, for the assignment of proteins to known families. Few

85 peptide sequences with lower confidence scores were manually searched using BLAST

86 (http://blast.ncbi.nlm.nih.gov). Finally, the relative abundance of each protein (\% of total venom

87 proteins) was estimated by integration of the peak signals at $215 \mathrm{~nm}$, using Chem Station B.04.01

88 (Agilent). When a peak from HPLC contained two or more SDS-PAGE bands, their relative

89 distribution was estimated by densitometry using the Image Lab v.2.0 software (Bio-Rad)

90 (Calvete, 2011).

91

92 Venom activities

93 Phospholipase A2 activity

94 Venom phospholipase $\mathrm{A}_{2}\left(\mathrm{PLA}_{2}\right)$ activity was determined on the monodisperse synthetic

95 substrate 4-nitro-3-octanoyl-benzoic acid (NOBA) (Holzer and Mackessy, 1996), in triplicate

96 wells of microplates. Twenty $\mu \mathrm{L}$ of venom solutions, containing $20 \mu \mathrm{g}$ protein, were mixed with

$9720 \mu \mathrm{L}$ of water, $200 \mu \mathrm{L}$ of $10 \mathrm{mM}$ Tris, $10 \mathrm{mM} \mathrm{CaCl}_{2}, 100 \mathrm{mM} \mathrm{NaCl}$, pH 8.0 buffer, and $20 \mu \mathrm{L}$ of

98 NOBA (0.32 mM final concentration). Plates were incubated at $37^{\circ} \mathrm{C}$, and the change in

99 absorbance at $425 \mathrm{~nm}$ was recorded after $20 \mathrm{~min}$ in a microplate reader (Awareness Technology).

\section{Proteolytic activity}

102 Proteolysis was determined upon azocasein (Sigma-Aldrich) as described by Wang et al.

103 (2004). Twenty $\mu \mathrm{g}$ of venoms were diluted in $20 \mu \mathrm{L}$ of $25 \mathrm{mM}$ Tris, $0.15 \mathrm{M} \mathrm{NaCl}, 5 \mathrm{mM} \mathrm{CaCl}$,

$104 \mathrm{pH} 7.4$ buffer, added to $100 \mu \mathrm{L}$ of azocasein $(10 \mathrm{mg} / \mathrm{mL})$ and incubated for $90 \mathrm{~min}$ at $37^{\circ} \mathrm{C}$. The

105 reaction was stopped by adding $200 \mu \mathrm{L}$ of $5 \%$ trichloroacetic acid. After centrifugation, $100 \mu \mathrm{L}$ of

106 supernatants were mixed with an equal volume of $0.5 \mathrm{M} \mathrm{NaOH}$, and absorbances were recorded

107 at $450 \mathrm{~nm}$. Experiments were carried out in triplicate. 


\section{L-amino acid oxidase activity}

110 L-amino acid oxidase (LAAO) activity was determined by adding various concentrations

111 of venom $(2.5-20 \mu \mathrm{g})$ in $10 \mu \mathrm{L}$ of water to $90 \mu \mathrm{L}$ of a reaction mixture containing $250 \mathrm{mM} \mathrm{L}-$

112 Leucine, $2 \mathrm{mM} o$-phenylenediamine, and $0.8 \mathrm{U} / \mathrm{mL}$ horseradish peroxidase, in $50 \mathrm{mM}$ Tris, $\mathrm{pH}$

1138.0 buffer, in triplicate wells of a microplate (Kishimoto et al., 2001). After incubation at $37^{\circ} \mathrm{C}$ for

$11460 \mathrm{~min}$, the reaction was stopped with $50 \mu \mathrm{L}$ of $2 \mathrm{M} \mathrm{H}_{2} \mathrm{SO}_{4}$, and absorbances were recorded at $115492 \mathrm{~nm}$.

\section{Cytotoxic activity}

118 Cytotoxic activity was assayed on murine skeletal muscle C2C12 myoblasts (ATCC CRL119 1772) as described by Lomonte et al. (1999). Venom (40 $\mu \mathrm{g})$ was diluted in assay medium 120 (Dulbecco's Modified Eagle's Medium [DMEM] supplemented with 1\% fetal calf serum [FCS]), 121 and added to subconfluent cell monolayers in 96-well plates, in $150 \mu \mathrm{L}$, after removal of growth 122 medium (DMEM with 10\% FCS). Controls for 0 and 100\% toxicity consisted of assay medium, 123 and $0.1 \%$ Triton X-100 diluted in assay medium, respectively. After $3 \mathrm{hr}$ at $37^{\circ} \mathrm{C}$, a supernatant

124 aliquot was collected to determine the lactic dehydrogenase (LDH; EC 1.1.1.27) activity released 125 from damaged cells, using a kinetic assay (Wiener LDH-P UV). Experiments were carried out in 126 triplicate.

\section{ACE inhibitory activity}

129 The angiotensin-converting enzyme (ACE) inhibitory activity of fraction 4 from the

130 HPLC separation (see Table 1), which was identified as a bradykinin-potentiating peptide-like

131 component, was assayed by the method of Cushman and Cheung (1971) with some modifications 132 (Kim et al., 1999). Various concentrations of the fraction, diluted in $20 \mu \mathrm{L}$, were added to $100 \mu \mathrm{L}$ 
133 of $10 \mathrm{mM}$ N-hippuryl-His-Leu substrate diluted in $2 \mathrm{mM}$ potassium phosphate, $0.6 \mathrm{M} \mathrm{NaCl}, \mathrm{pH}$

1348.3 buffer, and $5 \mathrm{mU}$ of ACE (EC 3.4.15.1; 5.1 UI/mg) diluted in 50\% glycerol. The reaction was

135 incubated at $37^{\circ} \mathrm{C}$ for $30 \mathrm{~min}$, and stopped by adding $200 \mu \mathrm{L}$ of $1 \mathrm{~N} \mathrm{HCl}$. The produced hippuric

136 acid was extracted by vigorous stirring for $10 \mathrm{sec}$, followed by the addition of $600 \mu \mathrm{L}$ of ethyl

137 acetate, and centrifugation for $10 \mathrm{~min}$ at $4000 \times \mathrm{g}$. An aliquot of $500 \mu \mathrm{L}$ of organic phase was

138 dried at $95^{\circ} \mathrm{C}$ for $10 \mathrm{~min}$. The residue was dissolved in $1 \mathrm{~mL}$ of water and, after stirring, the

139 absorbance was measured at $228 \mathrm{~nm}$. The percentage of ACE inhibition (\% ACEi) was

140 determined using the following formula; \% $\mathrm{ACEi}=(\mathrm{Abs}$ Control $-\mathrm{Abs}$ sample $) /(\mathrm{Abs}$ control -

141 Abs blank). Control absorbance corresponded to hippuric acid formed after the action of ACE,

142 while

143 blank absorbance was enzyme without substrate.

145 Statistical analyses

146 The significance of differences between means was assessed by ANOVA, followed by

147 Dunnett's test, when several experimental groups were compared with the control group, or by

148 Student's t-test, when two groups were compared. Differences were considered significant if $149 p<0.05$.

\section{RESULTS AND DISCUSSION}

152 B. punctatus has been included in the 'red list', a report categorizing conservation status,

153 as a threatened species (Carrillo et al., 2005). Very scarce information on its venom is available

154 in the literature. In comparative studies of snake venoms from Colombia (Otero et al., 1992) and

155 Ecuador (Kuch et al., 1996), respectively, this venom was found to induce local effects such as

156 hemorrhage, edema, and myonecrosis, as well as systemic alterations such as defibrination, in

157 similarity to venoms from other Bothrops species. Developments in proteomic techniques have 
158 brought new possibilities to examine the detailed toxin composition of snake venoms, increasing

159 knowledge on their evolution, toxicological properties, and correlation with clinical features of 160 envenomings (Calvete, 2007, 2013; Fox and Serrano, 2008; Valente et al., 2009; Ohler et al.,

161 2010). Therefore, the venom of B. punctatus was analyzed for the first time using proteomic

162 tools, to gain a deeper understanding on its protein composition and relationships to toxic and 163 enzymatic actions.

164 RP-HPLC of the crude venom resulted in the separation of 30 fractions (Fig.1C), which 165 were further subjected to SDS-PAGE (Fig.1B), in-gel digestion of the excised bands, and

166 MALDI-TOF-TOF analysis of the resulting peptides. The amino acid sequences obtained allowed 167 the unambiguous assignment of 29 out of the 37 components analyzed, to known protein families 168 of snake venoms (Table 1). Protein family relative abundances were estimated by integration of 169 the chromatographic areas, combined with gel densitometric scanning. Results showed that the 170 predominant proteins in this secretion are metalloproteinases (41.5\%; SVMP), followed by C171 type lectin/lectin-like proteins (16.7\%; CTL), bradykinin-potentiating peptide-like peptides 172 (10.7\%; PEP), phospholipases $\mathrm{A}_{2}$ of both the D49 (8.0\%) and K49 (1.3\%) subtypes (for a 173 combined 9.3\%; PLA 2 ), serine proteinases (5.4\%; SP), disintegrins (3.8\%; DIS), L-amino acid 174 oxidases (3.1\%; LAO), vascular endothelial growth factor (1.7\%; VEGF), and cysteine-rich 175 secretory proteins (1.2\%; CRISP), as summarized in Fig.2 and Table 1. An estimated 6.6\% of the 176 proteins remained unidentified, and owing to the scarcity of the venom, their assignment could 177 not be further pursued.

178 A recent phylogenetic analysis of the genus Bothrops (sensu lato) by Fenwick et al. 179 (2009) grouped B. punctatus within the same clade as Bothrops atrox and Bothrops asper. Since 180 the proteomic profile of the venoms of the latter two species has been reported (Núñez et al., 181 2009; Alape-Girón et al., 2008), a comparison of their venom compositions, together with those 182 of two other pitviper species distributed in Colombia, Bothrops ayerbei (Mora-Obando et al., 
184 these five species have been analyzed by the same methodological strategy, therefore allowing

185 reliable comparisons. The composition of $B$. punctatus venom resembles that of the other

186 Bothrops species listed in Table 2 only in terms of their high content of metalloproteinases (41.5-

$18753.7 \%$ ), but overall, its composition departs from the relative protein abundances observed in any

188 of the other four pitvipers. The high proportion of CTL proteins in B. punctatus is of note,

189 doubling the abundance observed in B. atrox, and close to that of B. ayerbei, while in contrast

190 such proteins are expressed only in trace amounts in B. asper, and have not been detected in $B$.

191 schlegelii (Table 2). Further, B. punctatus venom presents a modest amount of VEGF (1.7\%),

192 which has not been found in any of the venoms listed in Table 2. In similarity with the venom of

193 the arboreal snake $B$. schlegelii, but also with the terrestrial species $B$. ayerbei, the venom of $B$.

194 punctatus presents a high content of BPP-like peptides, strikingly differing from $B$. asper and $B$.

195 atrox venoms in this regard. The possible trophic relevance of these vasoactive peptides among

196 viperids remains elusive, and no clear correlations with prey types or habitats have been disclosed

197 thus far. BPPs are oligopeptides of 5-14 amino acid residues, rich in proline residues and often

198 presenting a pyroglutamate residue, which display bradykinin-potentiating activity. Their

199 pharmacological effect is related to the inhibition of angiotensin I-converting enzyme (ACE)

200 (Ianzer et al., 2007). Peak 4 of the HPLC separation of B. punctatus venom components (Fig.1C)

201 was identified as a BPP (Table 1), and its inhibitory activity on ACE was confirmed, showing a

202 half-maximal inhibition of this enzyme at $0.9 \mathrm{mg} / \mathrm{mL}$ (Fig.3A). Interest in snake venom BPPs

203 stems from their potential in the development of hypotensive drugs, as exemplified by Captopril ${ }^{\circledR}$.

204 Overall, the comparison of B. punctatus venom with those of other pitvipers distributed in

205 Colombia (Table 2) highlights the remarkable divergence of compositional profiles that have

206 arisen through the evolution and diversification of snakes (Casewell et al., 2013). 
The protein composition of $B$. punctatus venom correlates with the enzymatic activities

208

209

210

211

212

213

214

215

216

217

218

219

220

221

222

223

224

225

226

227

228

229

230

231

assayed, as well as with those described in earlier studies (Otero et al., 1992; Kuch et al., 1996).

L-amino acid oxidase (Fig.3C), proteolytic (Fig.4A), and PLA 2 (Fig.4B) activities of this venom

were corroborated. Interestingly, its proteolytic activity was higher than that of $B$. asper venom

(Fig.4A), and this might be related to the stronger hemorrhagic potency that was reported for $B$.

punctatus venom in comparison to B. asper venom (Otero et al., 1992). Hemorrhage induced by viperid venoms is mainly dependent on the proteolytic action of SVMPs upon the microvasculature and its extracellular matrix support (Bjarnason and Fox, 1994; Gutiérrez et al., 2005), and this effect can be enhanced by venom components affecting haemostasis, such as procoagulant SPs with thrombin-like activity, or some CTL components and disintegrins that potently interfere with platelets, among others (Gutiérrez et al., 2009; Calvete et al., 2005).

Considering that the proportion of SVMPs is lower in B. punctatus than in B. asper venom (Table 2), the higher hemorrhagic action reported for the former (Otero et al., 1992) suggests that its abundant CTL components (16.7\%) might include toxins that affect platelets, a hypothesis that deserves future investigation. On the other hand, the $\mathrm{PLA}_{2}$ activity of $B$. punctatus venom was lower than that of B. asper (Fig.4B), in agreement with their corresponding relative contents of these enzymes (Table 2). However, a major contrast was evidenced in the cytotoxic activity of these two venoms upon myogenic cells in culture, B. punctatus being essentially devoid of this effect, while B. asper causing overt cytolysis and LDH release under identical conditions (Fig.4C). Since cytolysis of myogenic cells, an in vitro correlate for in vivo myotoxicity (Lomonte et al., 1999), has been shown to be mediated mainly by basic PLA ${ }_{2} \mathrm{~S}$ in the case of viperid venoms (Gutiérrez \& Lomonte, 1995; Lomonte \& Rangel, 2012), this finding anticipates that the catalytically active (D49) PLA $_{2}$ s present in B. punctatus venom are likely to belong to the acidic type of these enzymes, which despite frequently having higher enzymatic activity than their basic counterparts, usually display very low, or even no toxicity (Fernández et al., 2010; 
232 Van der Laat et al., 2013). In contrast, the venom of B. asper is rich in basic D49 and K49

$233 \mathrm{PLA}_{2} \mathrm{~s} / \mathrm{PLA}_{2}$ homologues with strong cytolytic and myotoxic effects (Angulo \& Lomonte, 2005,

234 2009) that would explain the present findings. Although at least one PLA 2 component of $B$.

235 punctatus venom was shown to belong to the K49 type of catalytically-inactive, basic $\mathrm{PLA}_{2}$

236 homologues (fraction $23-25 \mathrm{a}$; Table 1), its low abundance (1.3\%) in the venom would be in

237 agreement with the observed lack of cytotoxicity (Fig.4C).

238 In summary, the general compositional profile of B. punctatus venom was obtained

239 through the analytical strategy known as 'snake venomics'. The present data add to the growing

240 body of knowledge on the remarkable diversity of compositional strategies in snake venom

241 'cocktails', in spite of the reduced number of gene families that encode their proteins/toxins

242 (Casewell et al., 2013; Calvete, 2013). Due to the key adaptive role of venoms, this knowledge,

243 in combination with toxicological, ecological, and natural history information, could lead to a

244 deeper understanding of the evolutionary trends and selective advantages conferred by particular

245 venom compositions in the divergence of snakes. In addition, compositional data may offer a

246 more comprehensive basis to foresee the features of envenomings by this pitviper species, largely

247 unreported in the literature.

\section{ACKNOWLEDGMENTS}

250

We thank Leidy Gómez, Paola Rey, and Wan-Chih Tsai for their valuable collaboration in

251 the laboratory.

\section{Funding}

This work was funded by grants obtained from Universidad de Antioquia Sostenibilidad

255 (2013-2014), and from Vicerrectoría de Investigación, Universidad de Costa Rica (project

256 "Network for proteomic characterization of snake venoms of medical and biological relevance in 
257 Latin America"; 741-B3-760). The Proteomics Laboratory of the Instituto Clodomiro Picado is

258 partially supported by the Vicerrectoría de Investigación, UCR. Maritza Fernández received a

259 Young Researcher Fellowship from COLCIENCIAS. The funders had no role in study design,

260 data collection and analysis, decision to publish, or preparation of the manuscript.

261

262 Competing Interests

263 Bruno Lomonte is an Academic Editor of PeerJ.

264

265 Author Contributions

266 Maritza Fernández and Andrés Pereáñez performed the experiments, analyzed the data, 267 and wrote the paper. Vitelbina Núñez conceived and designed the experiments, analyzed the data, 268 and wrote the paper. Bruno Lomonte performed the mass spectrometry analyses, analyzed the 269 data, and revised the paper. 
271

272

273

274

275

276

277

278

279

280

281

282

283

284

285

286

287

288

289

290

291

292

293

Alape-Girón A, Sanz L, Escolano J, Flores-Díaz M, Madrigal M, Sasa M, Calvete JJ. 2008. Snake venomics of the lancehead pit viper Bothrops asper: geographic, individual, and ontogenetic variations. Journal of Proteome Research 7: 3556-3571.

Angulo Y, Lomonte B. 2005. Differential susceptibility of C2C12 myoblasts and myotubes to group II phospholipase $\mathrm{A}_{2}$ myotoxins from crotalid snake venoms. Cell Biochemistry and Function 23: 307-313.

Angulo Y, Lomonte B. 2009. Biochemistry and toxicology of toxins purified from the venom of the snake Bothrops asper. Toxicon 54: 949-957.

Bjarnason JB, Fox JW. 1994. Hemorrhagic metalloproteinases from snake venoms. Pharmacology and Therapeutics 62: 325-372.

Calvete JJ. 2011. Proteomic tools against the neglected pathology of snake bite envenoming. Expert Reviews on Proteomics 8: 739-758.

Calvete JJ. 2013. Snake venomics: from the inventory of toxins to biology. Toxicon 75: 44-62.

Calvete JJ, Juárez P, Sanz L. 2007. Snake venomics, strategy and aplications. Journal of Mass Spectrometry 42: 1405-1414.

Calvete JJ, Marcinkiewicz C, Monleón D, Esteve V, Celda, Juárez P, Sanz L. 2005. Snake venom disintegrins: evolution of structure and function. Toxicon 45: 1063-1074.

Campbell JA, Lamar WW. 2004. The Venomous Reptiles of the Western Hemisphere. Ithaca, New York: Cornell University Press.

Carrillo E, Aldás S, Altamirano MA, Ayala-Varela F, Cisneros-Heredia DF, Endara A, Márquez C, Morales M, Nogales-Sornosa F, Salvador P, Torres ML, Valencia J, Villamarín-Jurado F, Yánez-Muñoz MH, Zárate P. 2005. Lista Roja de los Reptiles del Ecuador. Quito, Ecuador: Fundación Novum Milenium, Ministerio de Educación y Cultura. 
Casewell NR, Wüster W, Vonk FJ, Harrison RA, Fry BG. 2013.Complex cocktails: the evolutionary novelty of venoms. Trends in Ecology and Evolution, 28: 219-229.

Cushman DW, Cheung HS. 1971. Spectrophotometric assay and properties of the angiotensinconverting enzyme of rabbit lung. Biochemical Pharmacology 20: 1637-1648.

298

299

300

301

302

303

304

305

306

307

308

309

310

311

312

313

314

315

316

317

Daza JM, Quintana JC, Otero R. 2005. Bothrops punctatus (Chocoan forest pitviper) Herpetological Review 36: 338.

Fenwick AM, Ronald L, GutberleT JR, Jennafer AE, Parkinson CL. 2009. Morphological and molecular evidence for phylogeny and classification of South American pitvipers, genera Bothrops, Bothriopsis, and Bothrocophias (Serpentes: Viperidae). Zoological Journal of the Linnean Society 156: 617-640.

Fernández J, Gutiérrez JM, Angulo Y, Sanz L, Juárez P, Calvete JJ, Lomonte B. 2010. Isolation of an acidic phospholipase $\mathrm{A}_{2}$ from the venom of the snake Bothrops asper of Costa Rica: biochemical and toxicological characterization. Biochimie 92: 273-283.

Fox JW, Serrano SMT. 2008. Exploring snake venom proteomes: multifaceted analyses for complex toxin mixtures. Proteomics 8: 909-920.

Gutiérrez JM, Lomonte B. 1995. Phospholipase $A_{2}$ myotoxins from Bothrops snake venoms. Toxicon 33: 1405-1424.

Gutiérrez JM, Rucavado A, Escalante T, Díaz C. 2005. Hemorrhage induced by snake venom metalloproteinases: biochemical and biophysical mechanisms involved in microvessel damage. Toxicon 45: 997-1011.

Gutiérrez JM, Escalante T, Rucavado A. 2009. Experimental pathophysiology of systemic alterations induced by Bothrops asper snake venom. Toxicon 54: 976-987.

Holzer M, Mackessy SP. 1996. An aqueous endpoint assay of snake venom phospholipase $A_{2}$. Toxicon 34: 1149-1155. 

angiotensin-converting enzyme (ACE) I involve ACE-independent mechanisms? new Experimental Therapeutics 322: 795-805. oxidase. Analytical Biochemistry 298: 136-139. Toxicon 34: 714-717.

Lomonte B, Rangel J. 2012. Snake venom Lys49 myotoxins: from phospholipases $A_{2}$ to nonenzymatic membrane disruptors. Toxicon 60: 520-530.

\section{Lomonte B, Angulo Y, Rufini S, Cho W, Giglio JR, Ohno M, Daniele JJ, Geoghegan P,}

334 Gutiérrez JM. 1999. Comparative study of the cytolytic activity of myotoxic

Lomonte B, Escolano J, Fernández J, Sanz L, Angulo Y, Gutiérrez JM, Calvete JJ. 2008. and Bothriechis schlegelii. Journal of Proteome Research 7: 2445-2457.

\section{Lomonte B, Tsai WC, Ureña-Díaz JM, Sanz L, Mora-Obando D, Sánchez EE, Fry BG,} Gutiérrez JM, Gibbs HL, Calvete JJ. 2014. Venomics of New World pit vipers: genus- 
wide comparisons of venom proteomes across Agkistrodon. Journal of Proteomics 96: 103116.

344

345

346

\section{Mora-Obando D, Guerrero-Vargas J, Prieto-Sánchez R, Beltrán J, Rucavado A, Sasa M,} Gutiérrez JM, Ayerbe S, Lomonte B. 2014. Proteomic and functional profiling of the venom of Bothrops ayerbei from Cauca, Colombia, reveals striking interspecific variation with Bothrops asper venom. Journal of Proteomics 96: 159-172.

\section{Núñez V, Cid P, Sanz L, De La Torre P, Angulo Y, Lomonte B, Gutiérrez JM, Calvete JJ.} 2009. Snake venomics and antivenomics of Bothrops atrox venoms from Colombia and the Amazon regions of Brazil, Perú and Ecuador suggest the occurrence of geographic variation of venom phenotype by a trend towards paedomorphism. Journal of Proteomics 73: 57-78.

Georgieva D, Ohler M, Seifert J, von Bergen M, Arni RK, Genov N, Betzel C. 2010. Snake venomic of Crotalus durissus terrificus - correlation with pharmacological activities. Journal of Proteome Research 9: 2302-216.

Otero R. 1994. Manual de Diagnóstico y Tratamiento del Accidente Ofídico. Medellín, Colombia: Editorial Universidad de Antioquia.

Otero R, Osorio RG, Valderrama R, Giraldo CA. 1992. Efectos farmacológicos y enzimáticos de los venenos de serpientes de Antioquia y Chocó (Colombia). Toxicon 30: 611-620.

Paredes AE. 2012. Informe del Evento Accidente Ofídico. Vigilancia y Control en Salud Pública. Colombia: Instituto Nacional de Salud.

Valente RH, Guimarães PR, Junqueira M, Neves-Ferreira AG, Soares MR, Chapeaurouge A, Trugilho MR, León IR, Rocha SL, Oliveira-Carvalho AL, Wermelinger LS, Dutra DL, Leão LI, Junqueira-de-Azevedo IL, Ho PL, Zingali RB, Perales J, Domont GB. 2009. Bothrops insularis venomics: a proteomic analysis supported by transcriptomicgenerated sequence data. Journal of Proteomics 72: 241-255. 
366 Van der Laat M, Fernández J, Durban J, Villalobos E, Camacho E, Calvete JJ, Lomonte B.

367 2013. Amino acid sequence and biological characterization of BlatPLA $A_{2}$, a non-toxic acidic

368 phospholipase $\mathrm{A}_{2}$ from the venom of the arboreal snake Bothriechis lateralis from Costa

$369 \quad$ Rica. Toxicon 73: 71-80.

370 Wang WJ, Shih CH, Huang TF. 2004. A novel P-I class metalloproteinase with broad substrate-

371 cleaving activity, agkislysin, from Agkistrodon acutus venom. Biochemical and Biophysical

$372 \quad$ Research Communications 324: 224-230. 
373

374

375

376

377

378

379

380

381

382

383

384

385

386

387

388

389

390

391

392

393

394

395

396

397

Figure legends

Figure 1. Separation of Bothrops punctatus (A) venom proteins by RP-HPLC (B) and SDS-

PAGE (C). Venom was fractionated on a $\mathrm{C}_{18}$ column (C) by applying an acetonitrile gradient from 0 to $70 \%$ (dashed line), as described in Methods. Each fraction was analyzed by SDS-PAGE (B) under non-reducing (top gels) or reducing (bottom gels) conditions. Molecular weight markers (M) are indicated in $\mathrm{kDa}$, at the left. Tryptic digests of the excised protein bands were characterized by MALDI-TOF/TOF, as summarized in Table 1. The photograph of B. punctatus was obtained with permission from www.tropicalherping.com.

Figure 2. Composition of Bothrops punctatus venom according to protein families, expressed as percentages of the total protein content. SP: serine proteinase; $\mathrm{PLA}_{2}$ : phospholipase $\mathrm{A}_{2}$; CRISP: cysteine-rich secretory protein; DIS: disintegrin; PEP: bradykinin-potentiating peptidelike (BPP-like); LAO: L-amino acid oxidases; SVMP: metalloproteinase; VEGF: vascular endothelium growth factor; CTL: C-type lectin/lectin-like; UNK: unknown/unidentified.

Figure 3. Bothrops punctatus venom activities. (A) Inhibition of angiotensin-converting enzyme (ACE) by peak 4 of B. punctatus venom, identified as a BPP-like peptide (Table 1). Each point represents the mean $\pm \mathrm{SD}$ of three replicates. (B) L-amino acid oxidase activity of $B$. punctatus venom. Each point represents the mean $\pm \mathrm{SD}$ of three replicates.

Figure 4. Proteolytic (A), phospholipase $A_{2}$ (B), and cytotoxic (C) activities of Bothrops punctatus venom, compared to the venom of Bothrops asper. Proteolytic activity was determined on azocasein, using $20 \mu \mathrm{g}$ of each venom. Phospholipase $\mathrm{A}_{2}$ activity was determined 
399 determined on $\mathrm{C} 2 \mathrm{C} 12$ murine myoblasts, using $40 \mu \mathrm{g}$ of each venom, as described in Methods.

400 Bars represent mean $\pm \mathrm{SD}$ of three replicates. For each activity, differences between the two

401 venoms were significant $(\mathrm{p}<0.05)$.

402 


\section{Table 1 (on next page)}

Assignment of the RP-HPLC isolated fractions of Bothrops punctatus venom to protein families by MALDI-TOF-TOF of selected peptide ions from in-gel trypsin-digested protein bands. 
Table 1: Assignment of the RP-HPLC isolated fractions of Bothrops punctatus venom to protein families by MALDI-TOF-TOF of selected peptide ions from in-gel trypsin-digested protein bands.

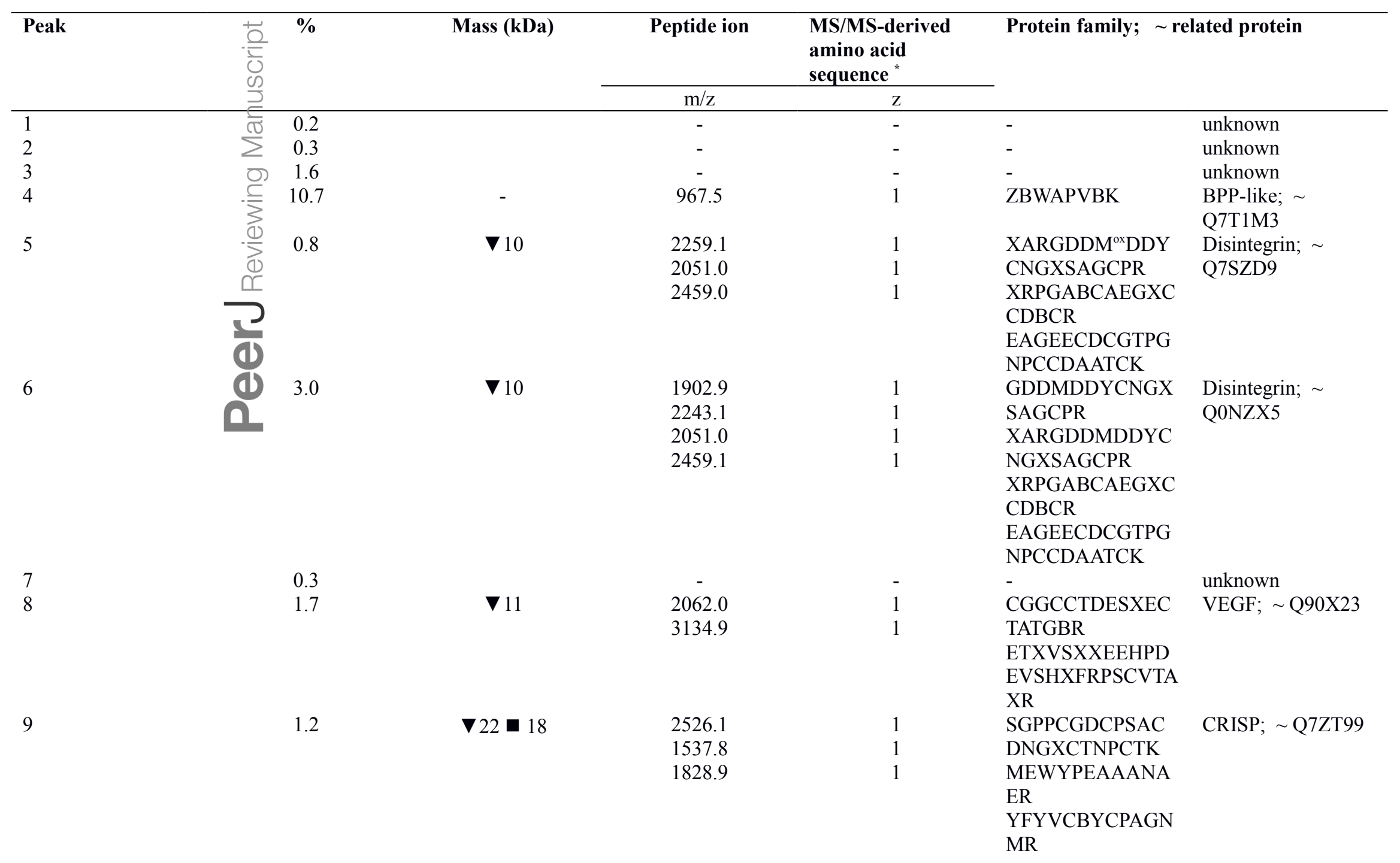




\begin{tabular}{|c|c|c|c|c|c|c|}
\hline $10 \mathrm{a}$ & 0.4 & $\nabla 38$ & 1561.9 & 1 & $\begin{array}{l}\text { SVPNDDEEXRYP } \\
\mathrm{K}\end{array}$ & $\begin{array}{l}\text { Serine proteinase; } \\
\text { Q5W960 }\end{array}$ \\
\hline \multirow[t]{11}{*}{$10 \mathrm{~b}$} & 0.2 & $\nabla 29 \square 28$ & 1206.8 & 1 & XMGWGTXSPTK & Serine proteinase; $~$ \\
\hline & & & 1683.2 & 1 & TYTBWDBDXMX & Q072L6 \\
\hline & & & 2534.5 & 1 & XR & \\
\hline & & & 1069.8 & 1 & VSYPDVPHCANX & \\
\hline & & & 1512.8 & 1 & NXXDYEVCR & \\
\hline & & & 3387.8 & 1 & FXVAXYTSR & \\
\hline & & & & & VXGGDECNXNE & \\
\hline & & & & & HR & \\
\hline & & & & & DSCBGDSGGPXX & \\
\hline & & & & & CNGBFBGXXSW & \\
\hline & & & & & GVHPCGBR & \\
\hline $10 \mathrm{c}$ & 0.3 & $\nabla 12 \square 22$ & - & - & - & unknown \\
\hline \multirow[t]{9}{*}{11} & 1.5 & $\nabla 28=20$ & 1288.7 & 1 & NFBMBXGVHSK & Serine proteinase; \\
\hline & & & 1190.7 & 1 & XMGWGTXSPTK & Q072L6 \\
\hline & & & 2305.4 & 1 & AAYPWBPVSSTT & \\
\hline & & & 1140.6 & 1 & XCAGXXBGGK & \\
\hline & & & 2477.5 & 1 & VSDYTEWXK & \\
\hline & & & 2477.4 & 1 & VSNSEHXAPXSX & \\
\hline & & & & & PSSPPSVGSVCR & \\
\hline & & & & & VXGGDECNXNE & \\
\hline & & & & & HR & \\
\hline $12 \mathrm{a}$ & 1.8 & $\nabla 35$ & 1083.7 & 1 & FXAFXYPGR & Serine proteinase; $\sim$ \\
\hline & & & & & & Q6IWF1 \\
\hline \multirow[t]{11}{*}{$12 b$} & 0.4 & $\nabla 29 \square 22$ & 1517.9 & 1 & NDDAXDBDXMX & Serine proteinase; $\sim$ \\
\hline & & & 1499.8 & 1 & VR & Q5W959 \\
\hline & & & 2294.3 & 1 & VVGGDECNXNE & \\
\hline & & & 1279.7 & 1 & HR & \\
\hline & & & 2889.7 & 1 & TNPDVPHCANXN & \\
\hline & & & 1083.7 & 1 & XXDDAVCR & \\
\hline & & & & & AAYPEXPAEYR & \\
\hline & & & & & XDSPVSNSEHXA & \\
\hline & & & & & PXSXPSSPPSVGS & \\
\hline & & & & & VCR & \\
\hline & & & & & FXAFXYPGR & \\
\hline $13-15$ & 0.8 & & - & - & - & unknown \\
\hline \multirow[t]{3}{*}{16} & 3.1 & $\nabla 16 \square 16$ & 1505.7 & 1 & CCFVHDCCYGK & Phospholipase $\mathrm{A}_{2}$, \\
\hline & & & 934.6 & 1 & YWFYGAK & D49; P86389 \\
\hline & & & 1966.1 & 1 & YXSYGCYCGWG & \\
\hline
\end{tabular}




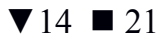

$\nabla 15 \square 16$

- 13

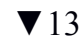

$\nabla 13-19$

- 120

$\nabla 53 \square$

$\nabla 13$
2605.5

2271.3

1388.8

1352.8
1636.0

1928.9
GXGBPK

DATDRCCFVHDC

CYGK

DNBDTYDXBYW

FYGAK

XDXYTYSBETGD

XVCGGDDPCBK

BXCECDRVAATC

FR

DCPPDWSSYEGH C-type lectin/lectin-

CYR

DNBDTYDXBYW

FYGAK

like; P22030

Phospholipase $\mathrm{A}_{2}$,

D49; C9DPL5

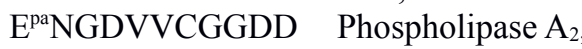

PCBK

CCFVHDCCYGK

DATDRCCFVHDC

CYGK

DATDRCCFVHDC Phospholipase $\mathrm{A}_{2}$

CYGK D49; Q9I968

-

D49; $\sim$ Q
unknown

DCPSDWSPYEGH C-type lectin/lectin-

CYR

unknown

ACSNGBCVDVNR Metalloproteinase;

AS

$\sim$ Q8AWI5

SAECTDRFBR

VVXVGAGMSGX

SAAYVXANAGHB

L-amino acid

VTVXEASER

oxidase;

BFGXBXNEFSBE

NENAWYFXK

XYFAGEYTABAH

GWXDSTXK

BFWEDDGXHGG

$\mathrm{K}$

SAGBXYEESXBK

NXBSSDXYAWXG C-type lectin/lectin-

XR

like; P22029 
23-25a

23-25b

23-25c

26

27

$28 \mathrm{a}$

$28 b$

$28 \mathrm{c}$

$29 \mathrm{a}$

$29 b$
1.3

1.1

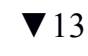

$\boldsymbol{\nabla} 28, \boldsymbol{\square} 20$

1533.7

1279.7

14.997

2294.1

1635.8

2040.2

1114.6

2257.3

1828.0

d

更
2.0

18.3

0.9

14.4

$\nabla 23 \square 42$

$\nabla 46 \square 2$

2.1

6.2

3.2

2.1

1

.2
.2

21

1457.0

1635.9

1193.6

2154.2

1609.9

1775.0

992.5
CYR

SYGAYGCNCGVX

GR

AAYPEXPAEYR

VVGGDECNXNE

HR

TNPDVPHCANXN

XXDDAVCR

NXBSSDXYAWXG

$\mathrm{XR}$

YXYXDXXXTGV

EXWSNK

XHBMVNXMK

DXXNVBPAAPBT

XDSFGEWR

YVEXFXVVDHG

MFMK

-

AY

ASM $^{\text {ox }}$ SECDPAEH

CTGBSSECPADVF

HK

XTVBPDVDYTXN

SFAEWR

TDXVSPPVCGNY

FVEVGEDCDCGS

PATCR

XVXVADYXM ${ }^{\text {ox }} \mathrm{F}$

XK

NXBSSDXYAWXG C-type lectin-like;

XR

P22029

TTDNBWWSR

XTVBPDVDYTXN

SFAEWR

Metalloproteinase;

XYEXVNTXNVX

$\sim$ Q8QG88

YR

YVEFFXVVDBGM

VTK

MNWADAER C-type lectin/lectin- 


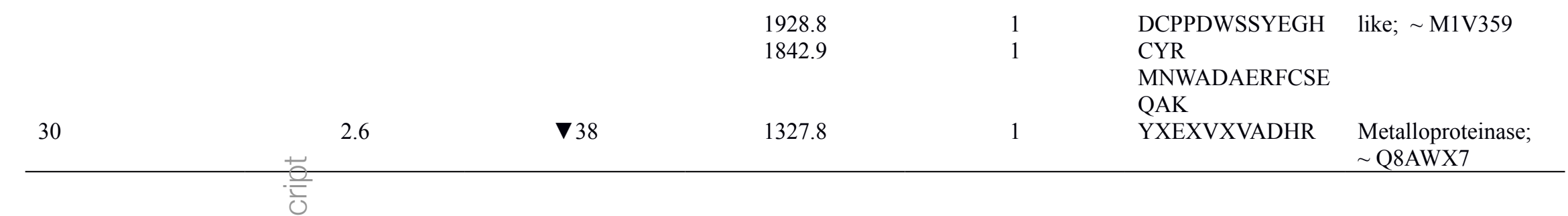

* Cysteine residues determined in MS/MS analyses are carbamidomethylated. X: Leu/Ile; B: Lys/Gln; ${ }^{\text {ox}}$ : oxidized; ${ }^{\text {pa: }}$ : propionamide;

$\boldsymbol{\nabla}$ : reduced, or $\mathbf{\square}$ : no

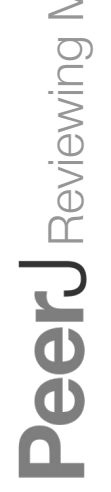




\section{Table 2 (on next page)}

Comparison of the venom composition of Bothrops punctatus with venoms from pitviper species distributed in Colombia 
Table 2. Comparison of the venom composition of Bothrops punctatus with venoms from pitviper species distributed in Colombia."

\begin{tabular}{|c|c|c|c|c|c|}
\hline Protein family & & & Snake species & & \\
\hline & ${ }_{B}^{B}$ othrops punctatus & Bothrops atrox ${ }^{\mathrm{b}}$ & Bothrops asper ${ }^{\mathrm{c}}$ & $\begin{array}{l}\text { Bothriechis } \\
\text { schlegelii }^{\mathrm{d}}\end{array}$ & Bothrops ayerbei ${ }^{\mathrm{e}}$ \\
\hline Metalloproteinase & 41.5 & 48.5 & 44.0 & 17.7 & 53.7 \\
\hline Phospholipase $\mathrm{A}_{2}$ & 9.3 & 24.0 & 45.1 & 43.8 & 0.7 \\
\hline Serine proteinase & 5.4 & 10.9 & 10.9 & 5.8 & 9.3 \\
\hline BPP-like & 10.7 & 0.3 & - & 13.4 & 8.3 \\
\hline CRISP & 1.2 & 2.6 & 0.1 & 2.1 & 1.1 \\
\hline $\begin{array}{l}\text { C-type lectin/lectin- } \\
\text { like }\end{array}$ & 16.7 & 7.1 & 0.5 & - & 10.1 \\
\hline VEGF & 1.7 & - & - & - & - \\
\hline L-amino acid oxidase & 3.1 & 4.7 & 4.6 & 8.9 & 3.3 \\
\hline Disintegrin & 3.8 & 1.7 & 1.4 & - & 2.3 \\
\hline Kazal type inhibitor & 3 & - & - & 8.3 & - \\
\hline Phosphodiesterase & (a) & - & - & - & 0.7 \\
\hline Nerve growth factor & (d) & - & - & - & 0.1 \\
\hline unknown & 6.6 & - & - & - & 1.7 \\
\hline Number of families & 9 & 8 & 7 & 7 & \\
\hline
\end{tabular}

* Although B. asper and B. schlegelii are found in Colombia, data correspond to venoms from specimens found in Costa Rica.

a present work; ' Núñez et al. (2009); ' Alape-Girón et al. (2008), specimens of Pacific versant; ${ }^{\mathrm{d}}$ Lomonte et al. (2008); ${ }^{\mathrm{e}}$ Mora-

Obando et al. (2014). 


\section{Figure 1}

Separation of Bothrops punctatus (A) venom proteins by RP-HPLC (B) and SDS-PAGE (C).

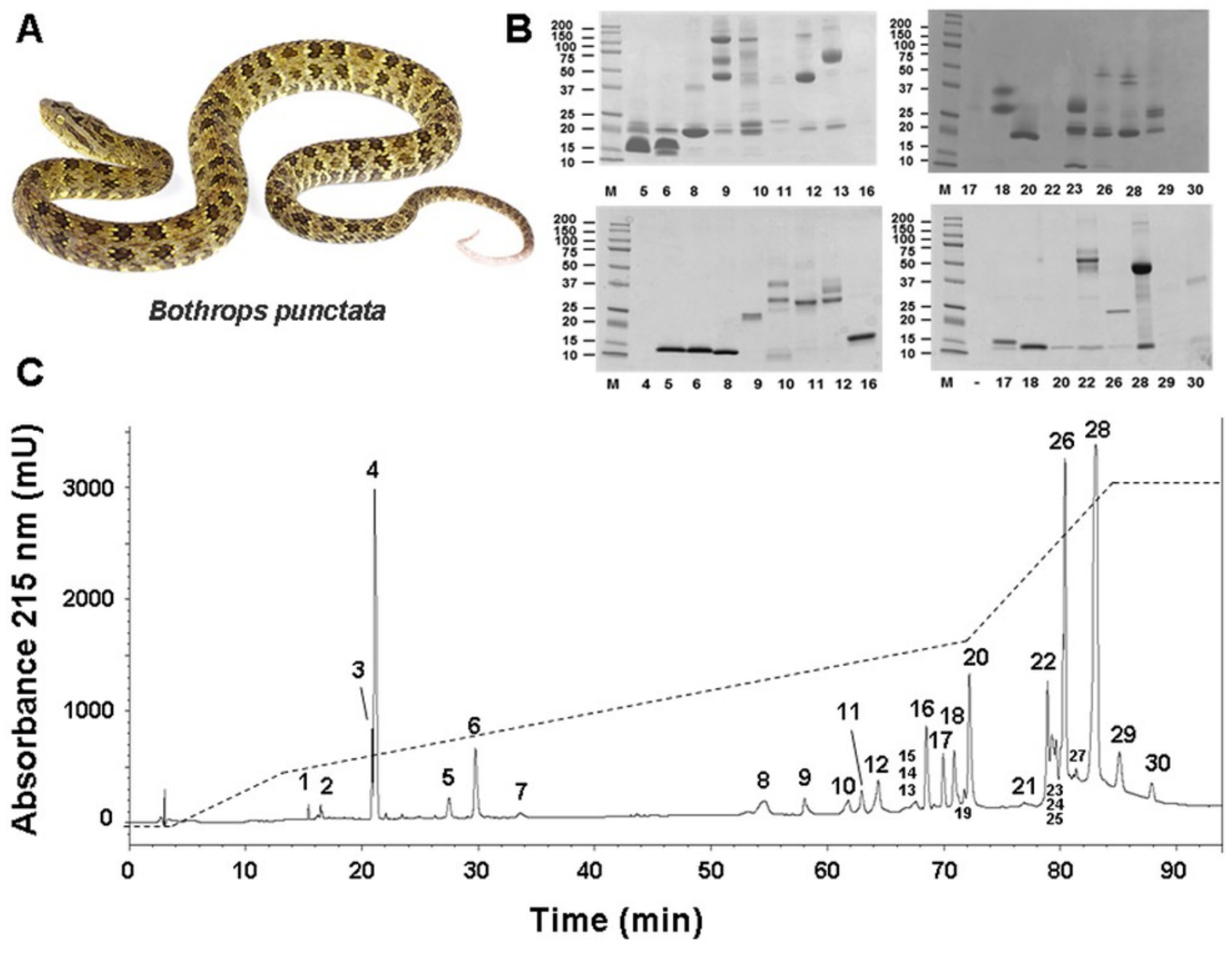




\section{Figure 2}

Composition of Bothrops punctatus venom according to protein families, expressed as percentages of the total protein content.

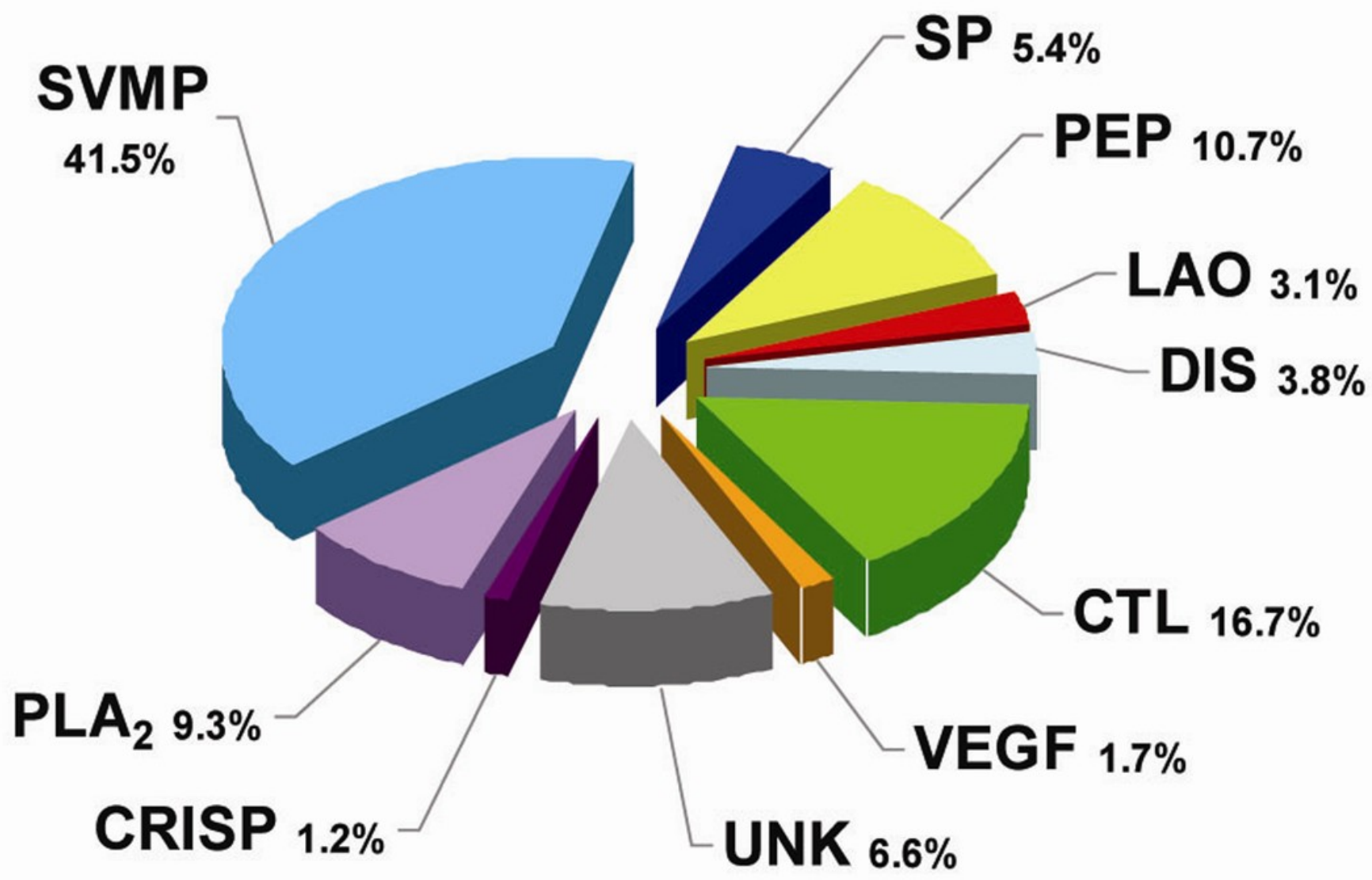




\section{Figure 3}

Bothrops punctatus venom activities.
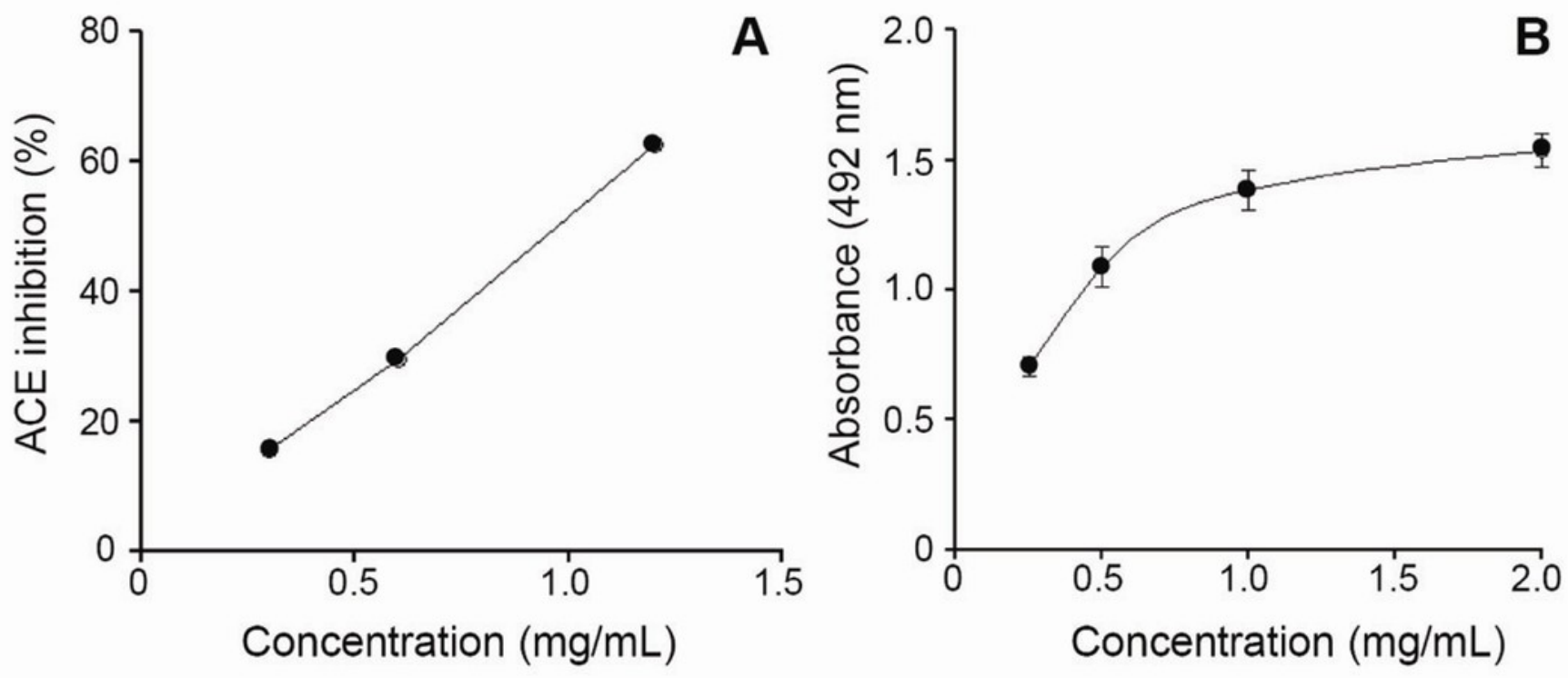


\section{Figure 4}

Proteolytic (A), phospholipase A2 (B), and cytotoxic (C) activities of Bothrops punctatus venom, compared to the venom of Bothrops asper. 

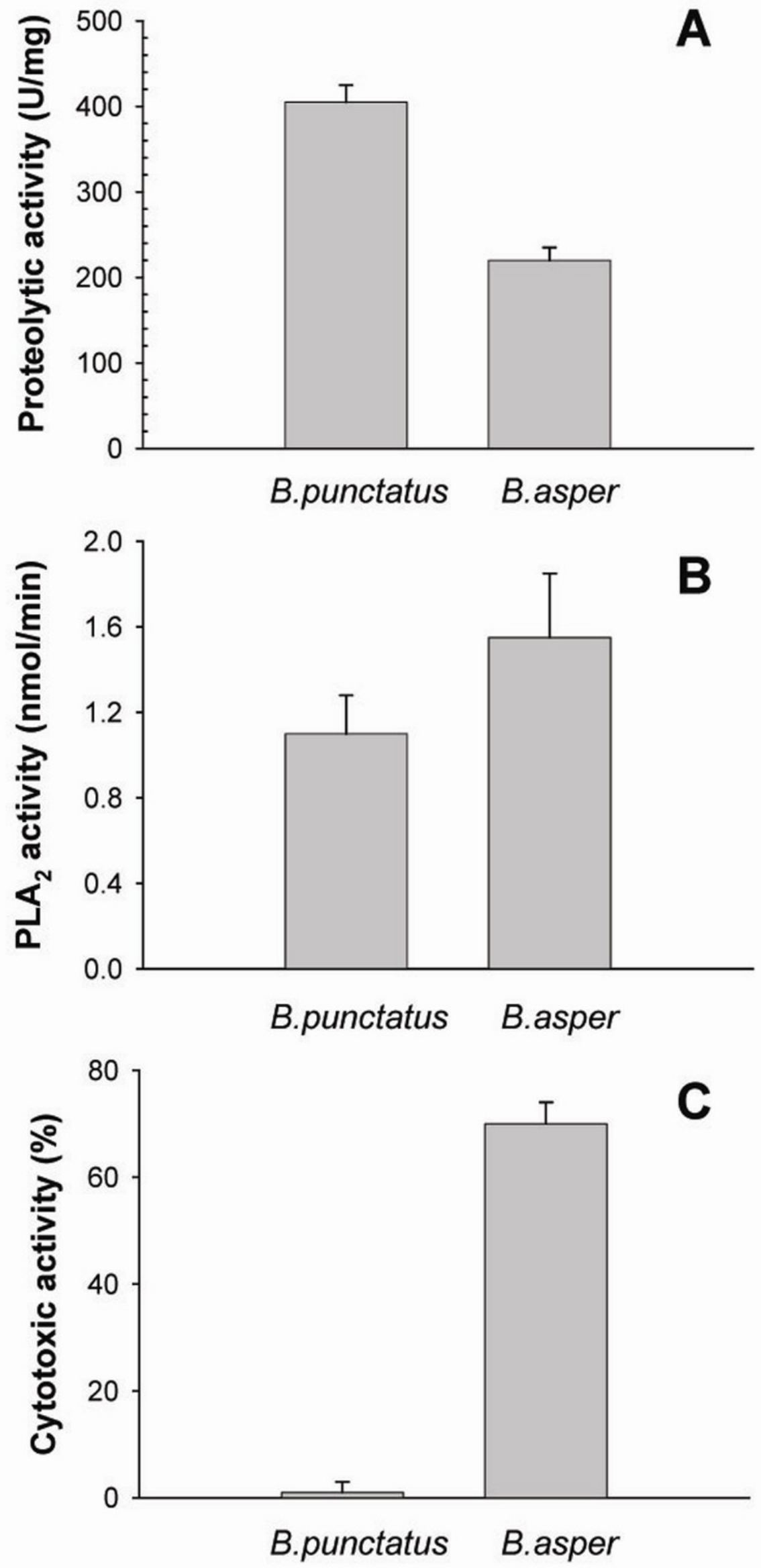